\title{
ZJEDNOCZENIE Z CHRYSTUSEM W KOŚCIELE NA PODSTAWIE TRYLOGII PASCHALNEJ WACŁAWA HRYNIEWICZA OMI
}

\section{WSTĘP}

Tajemnica osobowego zjednoczenia dokonująca się między człowiekiem a Bogiem zasadza się na tajemnicy osoby ludzkiej, która zawarta jest $\mathrm{w}$ jej otwartości na Boga. Człowiek jest istotą z natury ukierunkowaną na Boga i przeznaczoną do uczestnictwa w Jego życiu, tzn. do przebóstwienia, świętości. Ze struktury bytu ludzkiego wynika bowiem, że człowiek jest istotą wolną i zdolną do transcendencji, co sprawia, że nie wyczerpuje on swego istnienia $\mathrm{w}$ sobie samym. Jest bytem relacyjnym oraz jako taki nie może się spełnić sam $\mathrm{w}$ sobie, ale jedynie $\mathrm{w}$ relacji $\mathrm{z}$ innymi. Stanowi także byt ekstatyczny, zdolny do wychodzenia z siebie, byt

* Dorota Lekka - mgr teologii. W 2008 r. odbyła stypendium naukowe na Wydziale Teologii w Katholieke Universiteit Leuven w Belgii. W latach 2007-2008 była prezesem Koła Naukowego Teologów KUL. W 2009 r. ukończyła podyplomowe studia z retoryki stosowanej na Wydziale Filozofii KUL. W 2014 r. rozpoczęła studia doktoranckie z teologii dogmatycznej na Wydziale Teologii Uniwersytetu Kardynała Stefana Wyszyńskiego w Warszawie. 
dialogiczny i epikletyczny, tzn. bezsłownie przyzywający swego Stwórcę. W swej strukturze ontycznej jest otwarty na Boga i zawiera w sobie pewną dwuwymiarowość - naturę przyrodzoną i nadprzyrodzoną ${ }^{1}$. Nawet jeśli neguje któryś z tych wymiarów, to i tak niczego to nie zmienia w jego strukturze. Człowiek zatem całym swoim istnieniem jest wychylony w stronę Stwórcy. Bynajmniej same pragnienia i antropologiczne tęsknoty nie dają jeszcze człowiekowi udziału w Boskim życiu.

Dokonuje się ono w przestrzeni chwalebnego Ciała Chrystusa, jaką jest Kościół - powszechny sakrament zbawienia (por. KK 48). Za sprawą zbawczych wydarzeń Chrystusa uobecnianych w Kościele możliwe jest osobowe zjednoczenie człowieka z Bogiem. W nim Zmartwychwstały oddziałuje na bytową przemianę ludzkiej egzystencji.

Zaprezentowanie Hryniewiczowej wykładni dokonującego się zjednoczenia miedzy człowiekiem a Bogiem jest zasadniczym celem niniejszego artykułu. Wybór myśli teologicznej lubelskiego dogmatyka nie jest przypadkowy. Akcentuje on pozytywny wymiar łaski odkupienia podkreślając, że jego pierwszorzędnym owocem jest możliwość zjednoczenia z Bogiem, a dopiero później odkupienie grzechów. Co więcej, jego trzytomowy Zarys teologii paschalnej², stanowiący główne źródło

1 Prezentowana tu myśl Wacława Hryniewicza ukazuje, że człowiek nie może żyć inaczej, jak w sposób „dwunaturowy”. „Człowiek jest w pełni człowiekiem, gdy uczestniczy w życiu Boga i realizuje w sobie obraz Boży (idea uczestnictwa zakłada dynamiczną koncepcję człowieka jako bytu wolnego, teocentrycznego i otwartego na uczestnictwo w Bogu”. Zob. W. Hryniewicz, Tajemnica Chrystusa w teologii prawosławnej i protestanckiej, w: Jezus Chrystus. Historia i tajemnica, red. W. Granat, E. Kopeć, Lublin 1982, s. 440. Por. W. Hryniewicz, Bogoczłowieczeństwo, EK II, k. 714; tenże, Bóg naszej nadziei. Szkice teologiczno-ekumeniczne (dalej: BNN), Opole 1989, s. 122; tenże [współautor A. Nossol], Antropologia teologiczna, EK I, k. 694-698. Zob. także A. Bonora, Człowiek obrazem Boga w Starym Testamencie, tłum. J. Warzecha, „Communio” 1982, nr 2, s. 6-13; K. Góźdź, Teologia człowieka. Z najnowszej antropologii niemieckiej, Lublin 2006; Z. Kijas, Statyczność czy dynamiczność człowieka? Teologia „obrazu i podobieństwa” u H. U. von Balthasara, „Analekta Cracoviensia” 1995, nr 27, s. 173-191.

2 Sam Autor mówi o niej, że nie stanowi kolejnego traktatu teologicznego, ale jest „próbą spojrzenia na wiele zagadnień teologicznych w świetle wszechogarniającej tajemnicy Paschy Chrystusa”. Zob. Chrystus nasza Pascha: zarys chrześcijańskiej teologii paschalnej - tom 1, TNKUL, Lublin 1982 (dalej Pascha I), s. 32. Choć Hryniewicz podejmuje temat misterium paschalnego z perspektywy historycznej, liturgicznej, biblijnej, itp., to całość rozważań opiera się głównie na wymiarze konkretnym, osobowym i miste- 
prezentowanych tu treści, nie jest abstrakcyjną teorią. Posiada doniosły walor egzystencjalny, któremu sprzyja medytatywny styl. Charakteryzuje ją także niezwykły zmysł tajemnicy. Stanowi godny zauważenia egzemplarz teologii żywej i otwartej ${ }^{3}$.

ryjnym. Krótko mówiąc unika języka abstrakcji i polemiki, a skupia się na osobie Jezusa Chrystusa oraz jego wydarzeniu zbawczym wciąż obecnym w Kościele, dążąc do syntezy wielu ujęć i tradycji teologii paschalnej. Por. tamże, s. 30. Sam wyjaśnia, że świadomie dążył, aby język rozwijanej teologii $\mathrm{w}$ trzytomowym dziele nie miał tylko charakteru interpretacyjnego, ale by skłaniał do zadumy, doksologii, wyznania wiary i modlitwy. Por. Pascha Chrystusa w dziejach człowieka i wszechświata. Zarys chrześcijańskiej teologii paschalnej, t. III, Lublin 1991 (dalej: Pascha III), s. 17. Warto też dodać, że trylogia paschalna jest owocem wieloletnich wykładów Profesora na temat misterium paschalnego, rozpoczętych w 1966 r. w Katolickim Uniwersytecie Lubelskim. Jest próbą odpowiedzi na pytanie współczesnego człowieka o sens bycia chrześcijaninem, o istotę wiary chrześcijańskiej. Pierwszy tom - Chrystus nasza Pascha, skupia uwagę na jedności misterium paschalnego Chrystusa oraz sposobach jego interpretacji przez poszczególne tradycje: od Kościoła pierwotnego po czasy najnowsze. Tom drugi - Nasza Pascha $z$ Chrystusem [Zob. W. Hryniewicz, Nasza Pascha z Chrystusem. Zarys chrześcijańskiej teologii paschalnej, t. II, Lublin 1987 (dalej: Pascha II)] ukazuje Paschę Kościoła, która dokonuje się mocą wydarzeń zbawczych Chrystusa poprzez słowo i sakramenty. Tom trzeci - Pascha Chrystusa w dziejach człowieka $i$ wszechświata (Pascha III), stanowi zarys chrześcijańskiej antropologii i kosmologii paschalnej. Ukazuje Paschę człowieka, która dokonuje się w ciągu całego jego życia.

${ }^{3}$ Teologię Hryniewicza charakteryzuje niezwykły zmysł tajemnicy. Dlatego z upodobaniem sięga do teologii apofatycznej, która „Zwana również apofatyzmem jest sposobem myślenia teologicznego, ukształtowanym głównie w tradycji chrześcijaństwa wschodniego. Polega on na posługiwaniu się metodą negacji, antynomii, paradoksu, doświadczenia mistycznego i kontemplacji w poznaniu Boga i tajemnic wiary". Zob. W. Hryniewicz, Hermeneutyka $w$ dialogu. Szkice teologiczno-ekumeniczne, t. II, Opole 1998, s. 54. Apofatyczna wrażliwość intelektualna nie jest odrzuceniem pozytywnej drogi mówienia o Bogu, ale potrafi, w odczuciu Hryniewicza, bardziej wyrazić misterium Boga, którego poznanie ze strony istot stworzonych zawsze będzie niepełne. Teologię Hryniewicza cechuje także myślenie w kategoriach integralnych, komplementarnych. Unika skrajnych teorii i jest przeciwnikiem ich dogmatyzowania z pewnością, która nie znosi sprzeciwu. Jego zdaniem myślenie według całości przyczynia się skuteczniej do rozwoju refleksji teologicznej. Por. Pascha I, s. 32. Z upodobaniem sięga też do teologii wschodniej, prawosławnej, ekumenicznej. Unika abstrakcyjnej teorii skierowanej jedynie do wąskiej grupy studiujących przedmiot. Jego teologia, o charakterze bardzo personalistycznym, stanowi próbę osobistej refleksji nad tajemnicami wiary, kształtowaną w kontakcie z doświadczeniem innych chrześcijan, jak również w zasłuchaniu wobec pytań stawianych 
W niniejszym artykule zostanie przedstawiona myśl Wacława Hryniewicza na temat zjednoczenia z Chrystusem w Kościele. W pierwszym paragrafie ukazany będzie Kościół jako ciało Duchowe Chrystusa. Następnie zostanie omówione zjednoczenie z Chrystusem, które Hryniewicz wyjaśnia za pomocą takich kategorii, jak: przyczynowość osobowa (2.1), naśladowanie i uczestnictwo (2.2) oraz prawo synergizmu (2.3).

\section{KOŚClÓł JAKO ClAŁO DUCHOWE CHRYSTUSA}

Hryniewicz przypomina, że powstanie Kościoła ma trynitarną genezę, kształtowało się w ciągu całego życia Jezusa, a jego pełne objawienie $\mathrm{w}$ czasie dokonało się mocą wydarzeń paschalnych ${ }^{4}$. Rozwijając myśl powołuje się na liczne źródła patrystyczne, które ukazują powstanie Kościoła już w momencie śmierci Jezusa na krzyżu. Przebity bok i wypły-

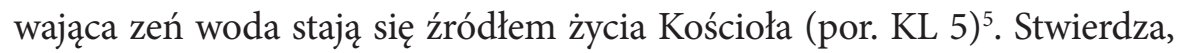
że cała wspólnota nowego ludu żyje z ofiarnego oddania się Chrystusa, mocą zmartwychwstania i zstąpienia Ducha Świętego. Przy tym od razu przypomina, że Kościół do swego zaistnienia potrzebuje każdego z tych

przez współczesnych, często niewierzących. Dlatego twórczość lubelskiego teologa posiada doniosły walor egzystencjalny, któremu sprzyja medytatywny styl, jako uprzywilejowana przez niego od lat forma uprawiania teologii. Zob. szerzej tenże, Hermeneutyka $w$ dialogu. Szkice teologiczno-ekumeniczne, s. 41-58; tenże, Apofatyczna teologia, EK I, k. 745-748; tenże, Kościót jest jeden. Ekumeniczne nadzieje nowego stulecia, Kraków 2004, s. 29-46; tenże, Przestrzeń wolności i odpowiedzialności teologa, w: Kościół poza Kościołem. Tydzień Eklezjologiczny 1999, red. K. Kowalik, A. Jarząbek, V. Kmiecik, Lublin 2001, s. 223-241.

${ }^{4}$ Takie ujęcie nie wyklucza dostrzegania obecności Kościoła już u początków historii zbawienia. Podkreśla jego pełne objawienie w Chrystusie. Por. Pascha II, s. 76. Zob. Sobór Watykański II, Konstytucja dogmatyczna o Kościele „Lumen Gentium”, w: Konstytucje, Dekrety, Deklaracje, Poznań 1968, nr 2-8 (dalej: KK); Jan Paweł II, Wierze w Kościół jeden, święty, powszechny $i$ apostolski, Watykan 1996, zwłaszcza nr 25-28; M. Rusecki, Boska geneza Kościoła, w: Kościół w czasach Jana Pawła II, red. tenże, K. Kaucha, J. Mastej, Lublin 2005, s. 66-77.

${ }^{5}$ Por. Pascha II, s. 78. Czerpiąc inspirację od Moltmanna, Hryniewicz przekonuje, że narodziny Kościoła na krzyżu prowadzą go ustawicznie pod krzyż. Kościołem Zmartwychwstałego pozostaje zaś wtedy, gdy potrafi przyjąć na siebie los Ukrzyżowanego. Dlatego uczestnictwo w jego funkcji kapłańskiej mają nie tylko kapłani, ale każdy chrześcijanin. Por. Pascha II, s. 79. 
wydarzeń, ponieważ wszystkie razem tworzą jedno niepodzielne misterium. By Kościół mógł stanowić sakrament zbawienia, potrzebuje, żeby śmierć Chrystusa nabrała powszechnego charakteru, a otrzyma go dzięki Zmartwychwstaniu i zesłaniu Ducha. Synteza chrystologicznego oraz pneumatologicznego wymiaru jest zdaniem lubelskiego teologa kwestią priorytetową we właściwym rozumieniu Kościoła. Pozwala dostrzec, że Kościół nie posiada istnienia sam w sobie, ale stanowi owoc posłannictwa Syna i Ducha, jest ich przedłużeniem w świecie, jak również dla świata. Ponadto rozumienie Kościoła w integralnej perspektywie paschalnej oraz akcentowanie osobowego działania Ducha Świętego wskazuje na żywotność wspólnoty Kościoła, jak też w ogóle decyduje o Kościele jako wydarzeniu zbawczym ${ }^{6}$. Uświadamia, że Kościół nie jest jedynie wspomnieniem swego Założyciela, ale Jego ustawiczną obecnością. Owa synteza chrystologicznego i pneumatologicznego wymiaru Kościoła, zdaniem Hryniewicza, ujawnia się najbardziej w pojęciu Kościoła jako ciała duchowego. Wyjaśnia, że Kościół jest ciałem Chrystusa, właśnie dlatego, iż jest ciałem duchowym przenikniętym przez Ducha ${ }^{7}$. To znaczy, że Duch Święty pełni funkcję konstytutywną nie tylko w powstaniu Kościoła, ale i w jego trwaniu.

${ }^{6}$ Por. Pascha II, s. 75.

${ }^{7}$ Innymi słowy Duch Święty nie tylko kieruje Kościołem, ale sprawia, że jest on Ciałem Chrystusa. Por. Pascha II, s. 93. „Przy użyciu kategorii „ciała” w eklezjologii eksponuje się integralną i organiczną więź wiernych z Chrystusem, znaczenie Chrystusa jako Głowy, a Ducha Świętego jako duszy, oraz komplementarność jedności i różnorodności w Kościele”. Zob. A. Czaja, Traktat o Kościele, w: Dogmatyka, t. II, red. E. Adamiak, A. Czaja, J. Majewski, Warszawa 2006, s. 387. Warto zauważyć, że lubelski ekumenista, konsekwentnie uprawiając teologię integralną, posługuje się różnymi obrazami Kościoła. Choć mówi w tym miejscu o Kościele jako ciele mistycznym Chrystusa, w innym opisuje Jego specyfikę w charakterze powszechnego sakramentu zbawienia, to w całej myśli teologicznej można bez większego problemu odnaleźć ideę Kościoła jako komunii. Tym bowiem, co Hryniewicz podkreśla najczęściej jest fakt Bożego planu co do wspólnoty z człowiekiem, który objawił się w całym wydarzeniu Chrystusa. Powołując zaś Kościół jako kontynuację swego zbawczego działania umożliwia wszystkim ludziom udział w podarowanych dobrach zbawienia, czyli osobowe zjednoczenie z Bogiem i ludźmi, które antycypuje eschatologiczną jedność. Zob. szerzej W. Kasper, Kościół jako wspólnota. Refleksje nad eklezjologiczną idea przewodnią Soboru Watykańskiego II, tłum. J. Świerkosz, „Communio" 1986, nr 6, s. 28-42; J. Ratzinger, Pielgrzymująca wspólnota wiary. Kościót jako komunia, tłum. W. Szymona, Kraków 2003; J.-M. R. Tillard, Church of Churches. The Ecclesiology of Communio, trans. R. C. De Peaux, O. Praem, Minnesota 1992. 
Hermeneutyczny klucz komplementarności ma u Hryniewicza zastosowanie także przy omawianiu misterium Kościoła. Jest głęboko przekonany, że nie można oddzielać jego rzeczywistości od jednoczesnego działania Chrystusa i Jego Ducha. Dlatego bardzo mocno odcina się od wszelkich chrystomonistycznych interpretacji, jak i od przesadnego akcentowana roli Ducha. Przykładem takiego ujęcia, jest rozpowszechnione jeszcze do niedawna, myślenie o Kościele w kategoriach inkarnacjonistycznych ${ }^{8}$. Niedoskonałości modelu stworzonego przez Johanna Adama Möhlera, który przedstawia Kościół jako kontynuację Wcielenia, są rozliczne. Hryniewicz zarzuca mu przede wszystkim brak podkreślenia wydarzeń paschalnych, a zwłaszcza osobowego posłannictwa Ducha Świętego. Model ten zauważa także znaczenie elementów widzialnych i organizacyjnych. Ponadto wcielenie Jezusa i Jego obecność w Kościele są utożsamiane aż do podkreślania organicznej ciągłości, co w dzisiejszych próbach konstruowania eklezjologii oddolnej widoczne jest w ukazywaniu Kościoła jako kontynuacji ziemskiego działania Jezusa. Tymczasem, choć nie można mówić o Kościele bez Chrystusa, nie można zapominać o jakościowej różnicy jaka między nimi istnieje. Chrystus pozostanie zawsze większym. Jako Głowa swojego duchowego Ciała będzie zawsze tym, który określa Kościół i wyznacza jego cel. Jako Zmartwychwstały jest osobą eschatologiczną, która streszcza w sobie przyszłe dzieje ${ }^{9}$.

Kościół nie jest rzeczywistością tylko boską, ale składa się także z konkretnych ludzi, którzy go tworzą, a którzy nie są wolni od grzechu. Powołując się na nauczanie Konstytucji dogmatycznej o Kościele, Hryniewicz pisze, że Kościół jest złożoną rzeczywistością, która jedynie na zasadzie bliskiej analogii upodabnia się do tajemnicy Słowa Wcielonego (por. KK $1-8)^{10}$. „Jak bowiem przybrana natura ludzka służy Słowu Bożemu za żywe narzędzie zbawienia, nierozerwalnie z Nim zjednoczone, nie inaczej

8 Por. Pascha II, s. 67-72. Model inkarnacjonistyczny pojawił się w XIX w. i został wypracowany głównie przez J. A. Moehlera. Jego przeciwwagą jest próba interpretacji H. Mühlena, który pojmuje Kościół jako kontynuację namaszczenia Jezusa przez Ducha Świętego. Por. tamże, s. 70. Zob. szerzej A. Czaja, Jedna Osoba w wielu osobach. Pneumatologiczna eklezjologia Herberta Mühlena, Opole 1997, s. 85-150; tenże, Traktat o Kościele, dz. cyt., s. 381.

9 Por. Pascha I, s. 24 29, Pascha II, s. 69.

${ }^{10}$ Por. Pascha II, s. 69. 
też społeczny organizm Kościoła służy ożywiającemu go Duchowi Chrystusowemu ku wzrastaniu ciała" (KK 8). Z przytoczonego tekstu wynika, że dzięki Duchowi to, co boskie tworzy z tym, co ludzkie jedną rzeczywistość zespoleniową ${ }^{11}$, jedno mistyczne Ciało Chrystusa. Ta jedność jest w stanie godzić boskie i ludzkie, widzialne i niewidzialne, święte i grzeszne, charyzmatyczne i zorganizowane w jednej rzeczywistości Kościoła. Jego misterium tkwi w tym, że jest jednocześnie zakorzeniony w Bogu, ale istnieje w historii. Ludzka strona Kościoła jest znakiem, którym posługuje się Duch Święty dla objawienia w nim boskiego elementu. Hryniewicz porównuje ją z glinianym naczyniem, który zawiera skarb Bożej tajemnicy. To, co jest dla niego darem stanowi jednocześnie zadanie, które ma być ciągle podejmowane, dążąc do swego pierwowzoru. Wynika to $\mathrm{z}$ teandrycznej natury Kościoła, który - stanowiąc owoc przede wszystkim Boskiej aktywności pozostawia przestrzeń dla ludzkiego współdziałania ${ }^{12}$.

Tego typu dialektyka dar - zadanie ujawnia się przy rozpatrywaniu przymiotów Kościoła, najbardziej w ramach analizy jednoczesnego istnienia świętości i grzeszności w Kościele, której Hryniewicz poświęca wiele miejsca. Wyjaśnia, że pojęcie świętości nie ogranicza się jedynie do obiektywnej sfery nauki, sakramentów, instytucji (świętość obiektywna), ani też nie wyczerpuje się w moralnej doskonałości większości jego członków (świętość subiektywna). Zdaniem Hryniewicza, decyduje o niej przede wszystkim fakt Bożego wybrania oraz wezwania do świętości, zbawczego posłannictwa ${ }^{13}$. To sam Bóg gromadząc nowy lud i przenikając go swoim działaniem jest źródłem jego świętości. Obdarzając nią powołuje Kościół jednocześnie do jej przekazywania. To znaczy, że Kościół jest święty „ze względu na swoje zadanie, a także zbawcze posłannictwo, które otrzymał od Chrystusa, nadal w nim obecnego mocą Ducha Świętego" ${ }^{14}$. Innymi słowy, świętość nie stanowi własności Kościoła, ale jest jego ustawicznym imperatywem do stawania się tym, czym powinien być według Bożego zamysłu. Taki ontyczny status Kościoła wcale nie eliminuje w nim obecności grzechu i zła. Kościół nie jest bowiem abstrakcyjną wielkością, oderwaną

${ }^{11}$ Por. W. Granat, Kościół - rzeczywistość zespoleniowa (realitas complexa), w: Z zagadnień kultury chrześcijańskiej, red. tenże, Lublin 1973, s. 43-58.

12 Por. Pascha II, s. 173.

13 Por. Pascha II, s. 120.

${ }^{14}$ Pascha II, s. 120. 
od ludzkiego życia a uświęcające działanie Chrystusa oraz Ducha Bożego nie zmienia automatycznie ludzkich skłonności do zła. W swej ziemskiej egzystencji jest złożony z konkretnych ludzi, których grzechy i niewierności rzutują na niego samego ${ }^{15}$. Jest wspólnotą mieszaną, w której według słów przypowieści Chrystusa, wyjaśnia Hryniewicz, jak pszenica miesza się z plewami, tak świętość z grzechem. Granica między jednym i drugim przebiega (najczęściej) we wnętrzu samego człowieka.

Hryniewicz posługuje się patrystyczną alegorią nierządnicy, której Chrystus nie przestaje obmywać swoją krwią, aby uczynić z niej nieskalaną oblubienicę. W ten sposób daje do zrozumienia, że Kościół, choć święty jako całość, sam z siebie nie jest w stanie osiągnąć świętości. Wciąż potrzebuje oczyszczenia i przemieniającej mocy zmartwychwstania, którą czerpie z udziału w misterium Paschy oraz Pięćdziesiątnicy, uobecnianego w sakramentach. Podkreśla, że świętości nie można stawiać na tej samej płaszczyźnie co grzechu; jest zawsze większa, niesie obietnicę, że mimo grzechu poszczególnych członków Kościół jako całość zostanie zachowany od sprzeniewierzenia się Bogu ${ }^{16}$. Dopóki jednak pielgrzymuje, przedłuża się w nim stan Paschy,

${ }^{15}$ Hryniewicz rozwija szeroko problem grzeszności Kościoła. Zob. Pascha II, s. 122-142. Twierdzi, że grzechy członków Kościoła nie naruszają wprawdzie jego ontologicznej tajemnicy, ale w jakiś sposób padają na niego cieniem. Zwraca uwagę na wahania Soboru Watykańskiego II, co do podmiotu winy Kościoła. Chodzi o unikanie sformułowania „Kościół grzeszny” i mówienie o przezwyciężeniu grzechu w jego członkach (por. KK 36, 48). Sam staje na stanowisku, że to wszystko, co Sobór odnosi do wiernych, należy odnieść do Kościoła jako całości. Tłumaczy rzecz następująco: „Grzeszny jest także Kościół, który tworzymy. On sam staje się w pewnym sensie podmiotem grzechu i winy swoich członków (jakkolwiek nie w tym samym znaczeniu, co poszczególny człowiek, który popełnia grzech). Ich wina spada na niego samego". Pascha II, s. 129-130. Zob. także refleksje H. U. von Balthasara na temat grzeszności Kościoła: H. U. von Balthasar, W pełni wiary, tłum. J. Fenrychowa, Kraków 1991, s. 67-377.

${ }^{16}$ Zdaniem Hryniewicza grzeszność odsłania kenotyczny wymiar Kościoła. Jego cierpienie, z powodu własnej winy, jest już udziałem w odkupieńczej tajemnicy Chrystusa oraz przedłużeniem Jego kenozy. Por. Pascha II, s. 137-141; 175-176. Hryniewicz pisze: „Uczestnictwo w krzyżu Chrystusa nie jest abstrakcyjną prawdą dla Kościoła. Ujawnia się ono w jego cierpieniu wskutek popełnionych win, w poczuciu winy, a nie jednokrotnie i bezradności w obliczu mrocznej strony ludzkiego życia [...]. Cierpienie Kościoła jest swoistą manifestacją tajemnicy krzyża Chrystusa i udziałem w Jego cierpieniach (por. Flp 3,10)". Pascha II, s. 139-140. 
czyli ciągłego przechodzenia jego członków ze stanu śmierci do życia, z grzechu do świętości. W ten sposób „Pascha Kościoła jest Paschą konkretnych ludzi oraz ich konkretnego życia" ${ }^{17}$. Staje się udziałem Kościoła, gdy współdziała z Duchem przez słowo, sakramenty i czyn miłości ${ }^{18}$. Te trzy płaszczyzny posługiwania Kościoła musi cechować zasada równowagi, jeśli Kościół ma spełnić swoje przeznaczenie. W ten sposób misterium paschalne trwa nadal w Kościele i poszczególnym człowieku. Spełni się dopiero w paruzji. Tymczasem w stanie pielgrzymowania Kościół dopiero dąży do eschatologicznego spełnienia „dopełniając udręk Chrystusa” (por. Kol 1,24). Nie jest definitywnym Królestwem Bożym, ale zmierza do niego, ,jest tymczasowo i prowizorycznie rozbitym namiotem wędrującego ludu Bożego"19.

W tej perspektywie eklezjalna świętość, która jest darem Boga w Chrystusie i dziełem Ducha Świętego, objawia Kościół jako rzeczywistość, która istnieje nie sama dla siebie, ale dla uświęcenia, jak również przemiany całego świata. Ekonomia eklezjalna to kontynuacja postępowania Boga, który przyszedł, aby wszystkich ludzi powołać do wspólnoty ze sobą. Jego paschalne oddanie, jak też ofiarny trud musi znaleźć w Kościele swoje przedłużenie. Kościół jest bowiem powołany, aby uczestniczyć w posłaniu Chrystusa względem ludzi, w ten sposób bezinteresownie służyć wszystkim w dziele ich zbawienia. Zdaniem Autora trylogii paschalnej należałoby raczej powiedzieć, że „to nie tyle Kościół ma do spełnienia pewną misję w świecie, ile właśnie ta misja, pochodząca z posłannictwa Syna i Ducha Świętego, tworzy Kościół i w nim się przedłuża”20. Zmartwychwstały istnieje nadal we wspólnocie eklezjalnej jako ten, który służy. Jego obecność, jak też zbawcza misja jaką powierzył Kościołowi decyduje o miejscu jego urzeczywistniania się. Hryniewicz mocno podkreśla, że to obecność Zmartwychwstałego decyduje o Kościele, a nie Kościół o niej. Twierdzi, że nie ogranicza się ona tylko do widzialnych granic Kościoła, ale istnieje tam, gdzie jest Chrystus, w miejscu działania Ducha Świętego ${ }^{21}$.

17 Pascha II, s. 142.

${ }_{18}$ Por. Pascha II, s. 66; 143. W ten sposób uobecnia się tajemnica Paschy Chrystusa w Kościele i w poszczególnych ludziach.

19 Pascha II, s. 173.

20 Pascha II, s. 65.

${ }^{21}$ Hryniewicz mocno akcentuje, że ta powszechna obecność konkretyzuje się 
Powszechność Kościoła wynika jego zdaniem z faktu nieograniczonego zasięgu zbawczego działania zmartwychwstałego Pana oraz obecności Jego Ducha. Dotyczy nie tylko przestrzeni, ale także czasu, sprawiając, że dzieło odkupienia to wydarzenie nieprzemijające i wiecznie trwałe dla wszystkich ludzi dobrej woli. W ten sposób katolickość Kościoła jest także przyczyną jego jedności. Dzięki niej każdy może stać się uczestnikiem zbawienia.

Jako jeden, święty, powszechny i apostolski, Kościół pozostaje znakiem obecności Chrystusa i Ducha Świętego w świecie ${ }^{22}$. Nawet jeśli w codziennym życiu trudno w nim rozpoznać oblicze Zmartwychwstałego, nie przestaje być powszechnym sakramentem zbawienia dla ludzkości. Nie tylko wskazuje na tajemnicę Trójjedynego Boga, ale uobecnia Jego misterium umożliwiając osobowe zjednoczenie między człowiekiem a Bogiem. Dlatego Hryniewicz zapewnia: „Kościół jest ustawicznym uobecnianiem całego paschalnego misterium Chrystusa, uobecnianiem, które przeszłość czyni teraźniejszością, a przyszłość antycypacją" ${ }^{23}$. Ten proces dokonuje się mocą Ducha za pośrednictwem słowa, wiary, sakramentów i posługiwania. Poprzez uczestnictwo w nim ludzie wszystkich czasów mają możliwość osobowego zjednoczenia, egzystencjalnej przemiany, ale też duchowego zmartwychwstania wraz z Chrystusem.

\section{ZJEDNOCZENIE Z CHRYSTUSEM}

Odkupienie jest umieszczeniem po prawicy Bożej Chrystusa, w którym każdy poszczególny człowiek staje się zdolny przyjąć przebaczenie i wziąć udział w życiu Boga. Chwalebne człowieczeństwo Chrystusa oraz działanie Jego Ducha w Kościele sprawiają, że zbawienie przenika ludzką egzystencję dokonując jego przemiany.

także w najbardziej potrzebujących. Po zmartwychwstaniu Chrystus jest obecny w świecie w różnoraki sposób: w przepowiadaniu Ewangelii, sakramentach, we wspólnocie wierzących oraz w najuboższych. Ta różnoraka obecność wyznacza miejsce urzeczywistniania się Kościoła. Por. Pascha II, s. 153-154.

${ }^{22}$ Szerzej na temat przymiotów Kościoła zob. K. Kaucha, Znamiona Kościoła, w: Leksykon teologii fundamentalnej, red. M. Rusecki [i in.], Lublin-Kraków 2002, s. $1393-1396$.

${ }^{23}$ Pascha II, s. 71. 


\subsection{PRZYCZYNOWOŚĆ OSOBOWA}

By przybliżyć rozumienie zbawczego działania Chrystusa Hryniewicz posługuje się kategorią przyczynowości osobowej ${ }^{24}$. Podkreśla najpierw, że odkupienia, pojętego jako nowy wzorzec egzystencji zawarty w przemienionym człowieczeństwie Chrystusa, nie można sprowadzić wyłącznie do świadectwa i moralnego wzorca niezależnego od konkretnego sposobu realizacji odkupienia. Życie, postępowanie Jezusa nie jest bowiem tylko świadectwem, przykładem, które pociągają do naśladowania. Takie postrzeganie życia Jezusa wskrzesiłoby tylko stare błędy Pelagiusza, jak również teologii liberalnej, zubożając cały ontyczny realizm odkupienia ${ }^{25}$.

${ }^{24}$ Kategorię przyczynowości osobowej Hryniewicz zaczerpnął od Heriberta Mühlena. Szerzej na ten temat zob. A. Czaja, Heribert Mühlen. Audytor Ducha Świętego, w: Leksykon wielkich teologów XX/XXI wieku, red. J. Majewski, J. Makowski, Warszawa 2004, s. 297-316, zwłaszcza s. 300; T. Wilski, „Przyczynowość osobowa” a jedność działania Trójcy Świętej ad extra, „Studia Gnesnensia” 1977, nr 3, s. 7-27; W. Hryniewicz, Ku integralnej ontologii osoby ludzkiej, w: Tajemnica osoby. Wokół osoby i myśli ks. Wincentego Granata, red. I. Szumił, Lublin 1985, s. 366-380.

25 Tak właśnie widział rolę Jezusa Chrystusa Pelagiusz, tzn. jako „dającego dobry przykład”. Człowiek przez Jego naśladowanie miał się sam wyzwolić z grzechu i sam osiągnąć zbawienie. Odrzucił istnienie predestynacji i stwierdził, że każdy może być zbawiony własną mocą, więc łaska Boża nie jest jego zdaniem koniecznie potrzebna do zbawienia. Ma ona jedynie charakter pomocy, udzielanej wedle zasługi danego człowieka. Pelagianizm jako system został rozwinięty przez uczniów Pelagiusza: Celestiusza (V w.) i Juliana z Eclanum (ok. 386-454 r.). Zdecydowanym przeciwnikiem tego nurtu był św. Augustyn z Hippony (354-430 r.). Pelagianizm został potępiony przez dwa lokalne synody w Afryce Północnej (synody kartagińskie w 411 r. i 418 r.) i ostatecznie uznany ze herezję na Soborze w Efezie w 431 r. Por. G. O’Collins, E. G. Farrugia, Pelagianizm, w: Leksykon pojęć teologicznych i kościelnych, tłum. J. Ożóg i B. Żak, Kraków 2002, s. 237. W historii myśli teologicznej można także znaleźć teorię moralnego wpływu śmierci Jezusa Chrystusa, uknutą przez średniowiecznego logika, Piotra Abelarda (1079-1142). Zgodnie z tym poglądem, celem śmierci Jezusa był moralny (psychologiczny) wpływ na ludzkość w celu jej poprawy. Człowiek z powodu swoich grzechów potrzebował bowiem pomocy, przykładu, modelu, z którym mógłby się identyfikować. Teoria ta, częściowo sformułowana przeciw anzelmiańskiej teorii zadośćuczynienia, zaprzecza, że Chrystus umarł, aby wynagrodzić Bożej sprawiedliwości, ale uczy, że Jego śmierć była zamierzona, aby ukazać ludziom wielkość Bożej miłości, co prowadzi z kolei do zmiękczenia ich serc oraz do skruchy. Tak więc zadośćuczynienie nie jest skierowane do Boga, w celu otrzymania Jego sprawiedliwości, ale do człowieka w celu przekonania go do prawego 
Wzorzec osobowy Jezusa należy zdaniem Hryniewicza pojmować w całej jego głębi ontycznej i w całym realizmie osobowym. Przecież odkupienie, którym jest Chrystus zmartwychwstały, urzeczywistnia się jedynie w międzyosobowym oraz egzystencjalnym kontakcie. Chrystus ukrzyżowany, a następnie zmartwychwstały zmienia ludzkie życie przez swą realną obecność, osobowe oddziaływanie. Sięga ono w głąb człowieka, umożliwiając mu naśladowanie oraz ontyczne uczestnictwo w życiu $\mathrm{Boga}^{26}$.

Hryniewicz porównuje je z wpływem jednego człowieka na drugiego. Osoba ludzka -wyjaśnia - posiada zdolność przenikania w egzystencję drugiej osoby i dokonywania w niej przemiany, często od niej niezależnej. Wpływ jest tym większy, im silniejsza jest osobowość oddziałującego. Bóg zaś ma niesłychanie większą moc oddziaływania, ponieważ jest On bardziej obecny w stosunku do człowieka niż ktokolwiek z ludzi. Jego zbawczy wpływ uprzedza ludzki współudział oraz osobową decyzję. To osobowe przenikanie rozwija myśl, wyzwala człowieka z zamknięcia w sobie, jak też wprowadza go we wspólnotę osób. By jednak Chrystus zmartwychwstały mógł obdarzyć człowieka swoją obecnością, dar ten wymaga dobrowolnego przyjęcia ze strony ludzkiej wolności ${ }^{27}$.

Wyjaśniając kategorię osobowej przyczynowości, lubelski teolog odwołuje się do treści z zakresu teologii stworzenia. Tłumaczy, że miejscem urzeczywistnienia się zbawienia jest każdy konkretny człowiek, który jako stworzony na obraz Boży, powołany jest do tego, by osiągnąć w sobie podobieństwo do Boga. Przekonuje, że to wezwanie jest człowiekowi dane w ontycznym wyposażeniu, a równocześnie jest mu zadane i może być zrealizowane na drodze dobrowolnego współdziałania z Bogiem. $\mathrm{W}$ takim rozumieniu egzystencjalny oraz osobowy wpływ Chrystusa

postępowania. Por. http://www.theopedia.com/Moral_Influence_theory_of_atonement, [dostęp: 21.05.2009 r.]. Powyższa teoria nie stanowi jednak formy semi-pelagianizmu, ponieważ pierwszeństwo w zbawczym działaniu przypisuje Jezusowi. Ponadto, rozpatrywany przez Abelarda moralny wzorzec Chrystusa nie jest pozbawiony ontologicznego wymiaru. Chrystus, wpływając na ludzi swoim przykładem, pomaga im w naśladowaniu Go i rzeczywistość ta nie jest czymś autonomicznym. W perspektywie myśli Hryniewicza na temat ontologicznego wzorca osobowego staje się to bardziej czytelne.

26 Por. Pascha I, s. 415-416.

${ }^{27}$ Por. Pascha I, s. 400. 
odnawia w człowieku obraz Boży, prowadzi do wspólnoty z Nim. „Nie jest to jednak wzorzec o charakterze czysto moralnym, który domaga się zewnętrznego naśladownictwa. Jest to wzorzec ontyczny, osobowy, posiadający niesłychaną siłę przyciągania (por. J 12,32) i przemieniania ludzkiego wnętrza"28. Wskutek jego oddziaływania na każdą wolność, realizuje się w człowieku odkupienie. Przez otwarcie się na zbawczy wpływ Chrystusa człowiek dostępuje udziału w życiu samego Boga, a dzięki temu przebóstwienia, jak też wolności, których owocem jest pełne urzeczywistnienie się jego człowieczeństwa ${ }^{29}$.

\subsection{NAŚLADOWANIE I UCZESTNICTWO}

Hryniewicz mocno podkreśla w swych teologicznych rozważaniach ontyczny realizm odkupienia. W próbie ukazania jego aktualności dla współczesnego człowieka zaznacza, że nie chodzi o czysto zewnętrzne naśladownictwo dobrego przykładu, jaki dał Jezus Chrystus, ale o uczestnictwo w wydarzeniu, którym był i jest nadal - Jego osoba oraz zbawczy czyn. Jego zdaniem, „jeżeli istnieje niebezpieczeństwo «soteriologii przykładu» to tylko wtedy, gdy zredukuje się ją do «soteriologii naśladowania». Chodziło by wówczas bardziej o Chrystusa jako «nauczyciela rodzaju ludzkiego niż odkupiciela» [...]"30.

${ }^{28}$ Pascha I, s. 417. Zdaniem Hryniewicza taki sposób interpretacji odkupienia dochodzi do głosu u Pieta Schoonenberga. Por. Pascha I, s. 399.

29 Por. W. Hryniewicz, Współczesna antropologia prawosławna, „Analecta Cracoviensia” 1972, nr 4, s. 217 238; tenże, Człowiek - istota otwarta na uczestnictwo w Bogu, w: Być człowiekiem, red. T. Bielski, Poznań 1974, s. 233-255. Tę myśl rozwija też papież Jan Paweł II w encyklice Redemptor hominis. Stwierdza, że człowiek jako istota teocentryczna jest powołany do dynamicznego uczestnictwa w Bogu i w tajemnicy Chrystusa, która doprowadzi go do przebóstwienia. Por. Redemptor hominis, Watykan 1979, nr 10 (dalej: RH). Zob. W. Hryniewicz, Znaczenie patrystycznej idei przebóstwienia dla soteriologii chrześcijańskiej, „Roczniki Teologii Katolickiej 1980, nr 27, z. 2, s. 19-34.

${ }^{30}$ Pascha I, s. 398. Gdy Hryniewicz rozróżnia naśladownictwo od uczestnictwa to nie uważa, że kategorie te są sobie sprzeczne. Dokonuje tak mocnego rozróżnienia tylko dlatego, że przez niektórych kategoria naśladowania może być rozumiana w duchu pelagianizmu, jako czysto zewnętrzny i samodzielny akt ze strony człowieka, którym miałby sobie wysłużyć zbawienie. 
By dobrze zrozumieć sens tych słów należy odwołać się do jego innego dzieła - Bóg naszej nadziei. Przedstawia w nim prawosławne rozumienie „naśladowania Chrystusa”, ale ukazuje myśli, które są ważne dla niniejszego tematu. Przytacza bowiem głosy niektórych myślicieli, którzy zarzucają, że idea naśladowania sugeruje zbyt zewnętrzną postawę wobec Chrystusa ${ }^{31}$. Ich zdaniem jedyną drogą upodobnienia się do Chrystusa jest „zyskiwanie łaski udzielanej przez Ducha Świętego”, a nie naśladowanie, które łatwo można sprowadzić do ekstrynsecyzmu i moralizmu ${ }^{32}$. Hryniewicz stwierdza: „w odczuciu prawosławnych, duchowości «naśladowania» Chrystusa zagraża niebezpieczeństwo pomniejszania roli uczestnictwa w Jego uwielbionym człowieczeństwie, a więc w rezultacie roli przebóstwienia (theosis) mocą Ducha Świętego, które jest szczytowym momentem tego uczestnictwa"33. Słowa te zdawałyby się potwierdzać antynomię między ideą naśladowania a uczestnictwa: pierwsza wiąże się ściśle z zagadnieniem krzyża, druga zaś zmartwychwstania. Tymczasem Hryniewicz wyjaśnia, że istota sporu leży gdzie indziej. Jego zdaniem te dwie idee nie są względem siebie przeciwstawne, ale komplementarne. Uważa, że należy zachować równowagę między tymi dwoma dopełniającymi się elementami - naśladowaniem Chrystusa uniżonego (mimesis), a uczestnictwem (methexis) w Jego zmartwychwstałym życiu ${ }^{34}$. Zbawcze skutki misterium paschalnego to nie tylko wzorzec postępowania moralnego. Odkupienie ma miejsce wtedy, gdy staje się realnym udziałem człowieka. Ten zaś nie jest możliwy przez jego wysiłek ${ }^{35}$. Jest ontycznym

${ }^{31}$ Por. BNN, s. 99.

32 Por. tamże.

${ }_{33}$ BNN, s. 99.

${ }_{34}$ Por. BNN, s. 99. G. L. Mühller pisze: „Kto chce przyjąć Ewangelię o panowaniu Boga, ten musi wejść na drogę naśladowania Jezusa, to znaczy powinien razem z Nim kroczyć drogą Bożą, pomiędzy uniżeniem i wywyższeniem, brakiem dóbr ziemskich i obfitością łaski, między krzyżem i zmartwychwstaniem (zob. J 14,24 nn.). [...] Osobowa wspólnota $\mathrm{z}$ Jezusem przez wiarę i naśladowanie oznacza obecność Boga z nami na naszej drodze. Cel daje się nam jako droga. Historia życia każdego pojedynczego człowieka jako osoby i przeniknięte łaską dzieje całej ludzkości jawią się nam jako droga $z$ Bogiem (Synem), w Bogu (Duchu Świętym) i do Boga (Ojca)”. Tenże, dz. cyt., s. 436.

${ }^{35}$ Do podobnego wniosku doszedł kiedyś Luter, gdy rozważał, co musi zrobić, by znaleźć łaskę Chrystusa. Odpowiedź, którą on dał diametralnie różni się od perspektywy katolickiej, choć gdyby wyjąć pewne zdania z kontekstu, to trudno byłoby zauważyć tę 
i osobowym darem Chrystusa, jakkolwiek zależy od jego przyjęcia, zajęcia otwartej oraz dynamicznej postawy ze strony człowieka. Dzięki temu naśladowanie, postawa uczniowska, rozumiana jako aktywna odpowiedź człowieka na uprzedni Chrystusowy dar, jest równocześnie uczestnictwem, które prowadzi do przebóstwienia. Istota leży w tym, wyjaśnia Hryniewicz, by nie przeciwstawiać sobie mniej lub bardziej wyakcentowanego naświetlenia danych idei, które łatwo może doprowadzić do absurdu ${ }^{36}$.

\subsection{PRAWO SYNERGIZMU}

W rozważaniach Hryniewicza występuje często akcentowanie tajemnicy suwerenności Boga i jednoczesnego współdziałania człowieka. Ta logika Bożego działania uwidacznia się zwłaszcza w wydarzeniu paschalnym, które stanowi niepowtarzalny wypadek Jezusa Chrystusa, a równocześnie zawiera otwartą przestrzeń dla człowieka. Hryniewicz

różnicę. Luter stwierdził, że nic nie może zrobić, ponieważ zbawienie jest darem Chrystusa, więc człowiek nie może uczynić nic, by je osiągnąć. Dlatego sformułował słynne cztery tezy: sola gratia, sola fide, solus Christus i sola scriptura, które charakteryzują jego stanowisko. Perspektywę katolicką i stanowisko, które prezentuje Hryniewicz znamionuje mocne przekonanie, że zbawienie jest suwerennym darem Boga, na które człowiek nie może sobie zasłużyć. Ale jednocześnie, pokładanie w Bogu jedynie samej wiary nie wystarczy, jeśli nie idą za nią konkretne czyny i wysiłek współpracy, który jest wtórny wobec otrzymanego daru. Dlatego lubelski teolog tak często akcentuje obok suwerenności Bożego daru, konieczność aktywnej odpowiedzi ze strony człowieka.

${ }^{36}$ Por. Pascha I, s. 414. Hryniewicz wyraża tę myśl przedstawiając grecki ideał wychowania paidea. Idea uczestnictwa i naśladowania, dzięki którym Bóg wprowadza wierzącego w proces odkupienia i wyzwolenia, ukształtowała się w pierwszych wiekach chrześcijaństwa właśnie pod wpływem styku z myślą platońską. Hryniewicz, sygnalizując w zarysie grecki ideał wychowania, skupia uwagę na równoznaczności pojęć: naśladowania Bóstwa oraz przebóstwienia i uczłowieczenia. Grecka idea stała się modelem, który przejęli Ojcowie dla ukazania Chrystusa jako Tego, który przez swą wzorczą egzystencję prowadzi do dojrzałości i pełni człowieczeństwa: paideia en Christo. Celem tych jego krótkich wywodów jest próba przezwyciężenia antynomii między przebóstwieniem a uczłowieczeniem. Jest zdania, że stanie się podobnym do Bóstwa oznacza jednocześnie prawdziwe człowieczeństwo. Por. RH 10, Jan Paweł II, Encyklika „Dives in Misericordia”, Watykan 1980, nr 7-9. 
wyjaśnia, że współdziałanie człowieczeństwa Chrystusa solidarnie zespolonego z ludzkością dla jej dobra oraz zbawienia wyznaczyło odtąd „drogę ludzkiej synergia - współpracy z Bożym działaniem (por. 1 Kor 3,9; 2 Kor 6,1)"37.

Wszystko, czego dokonał Chrystus dla zbawienia człowieka musi stać się także jego udziałem, jeżeli chce on dostąpić tej samej chwały, którą został otoczony Zmartwychwstały. Dzieje się tak dlatego, wyjaśnia lubelski teolog, że cierpienie Chrystusa ma charakter inkluzywny, tzn. pozostawia ludzkiej wolności wolną przestrzeń do dopełnienia (por. Kol 1,24). Hryniewicz stwierdza, że: „suwerenność Bożego dzieła dokonanego w tajemnicy paschalnej Jezusa nie tylko nie wyklucza, ale wręcz wymaga ludzkiego włączenia się w to dzieło. Prawdziwie ludzka solidarność Jezusa ze wszystkimi nie polega na ich wyłączeniu. Przysługujące $\mathrm{Mu}$ jako Synowi Bożemu suwerenność i ekskluzywność niosą w sobie równocześnie moment inkluzywności" ${ }^{38}$. Dlatego aspekt współuczestnictwa, jak też współcierpienia należy do istotnej treści egzystencji, posłannictwa Kościoła, a w nim każdego człowieka.

Taki, zdaniem Hryniewicza, jest eklezjologiczny sens biblijnych, a zwłaszcza Pawłowych formuł określających wspólnotę losu człowieka z Chrystusem. Kategorie takie jak: współcierpienie, współofiarowanie, współumieranie, włączenie w śmierć i zmartwychwstanie, współuczestnictwo, współzmartwychwstanie ${ }^{39}$, opisują uczestnictwo człowieka w misterium paschalnym Chrystusa: „razem z Chrystusem zostałem przybity do krzyża” (Ga 2,19-21); udział w Jego cierpieniach (por. Flp 3,10); dopełnianie niedostatków udręk Chrystusa (por. Kol 1,24); „razem z Nim pogrzebani” (por. Kol 2,11-12); razem z Chrystusem umarliśmy (por. Kol 2,20; Kol 3,1-5);, „dawny nasz człowiek został razem z Nim współukrzyżowany” (por. Rz 6,4-11); „nosimy nieustannie w ciele naszym konanie Jezusa" (2 Kor 4,10-14); udział w Jego cierpieniach, upodobnienie się do Jego śmierci (por. Flp 3,10-11); ,jeste-

37 Por. Pascha II, s. 84.

${ }^{38}$ Pascha II, s. 84.

${ }^{39}$ Por. Pascha I, s. 110, 113, 129, 137, 161, 271, 389; Pascha II, s. 51, 73, 84. Wymienione strony służą tylko dla przykładu. Cała trylogia obfituje w tego typu sformułowania. 
ście uczestnikami cierpień Chrystusowych” (1P 4,13); „jesteśmy bowiem współuczestnikami Chrystusa" (Hbr 3,14) ${ }^{40}$.

Hryniewicz przekonuje, że Kościół, a w nim każdy człowiek, uczestniczy nie tylko w bycie i życiu Chrystusa zmartwychwstałego, lecz również w całym odkupieńczym akcie Jego śmierci oraz zmartwychwstania $^{41}$. Wyrazem tej prawdy są wymienione wyżej formuły chrystologiczne, które ukazują tajemnicę „naszej Paschy z Chrystusem”. W ujęciu Autora trylogii paschalnej wprowadzają one do idei uczestnictwa pewien element dynamizmu. Równocześnie Hryniewicz cały czas utrzymuje ontologiczny charakter tego uczestnictwa ${ }^{42}$. Tłumaczy, że początkiem udziału człowieka

${ }^{40}$ M. J. Harris wyjaśnia, że konanie Jezusa noszone w ciele wierzącego (2 Kor $4,10)$ odnosi się do chrztu identyfikującego ze śmiercią Jezusa, dziennego uśmiercania grzesznej natury lub stopniowego tracenia fizycznej siły wskutek służenia Chrystusowi. Autor stwierdza, że według Pawła celem utożsamienia się wierzącego z Jezusem w Jego cierpieniu (noszenie konania) jest zapewnienie możliwości zamanifestowania życia Jezusa zmartwychwstałego. Fizyczne bowiem ciało wierzącego jest miejscem, gdzie powtarzane są cierpienia Jezusa i gdzie w ten sposób objawia się moc Jego zmartwychwstania dzięki działaniu Ducha Świętego w poszczególnym wierzącym. Por. M. J. Harris, The Second Epistle to the Corinthians. A commentary on the Greek Text, Grand Rapids 2005, s. 346-347. Zob. także D. G. Powers, Salvation through Participation: on Examination of the Notion of the Believers' Corporate Unity with Christ in Early Christian Soteriology, Leuven 2001; R. C. Tannehil, Dying and Rising with Christ. A Study in Pauline Theologhy, Berlin 1967. Ostatnia pozycja, choć wydana stosunkowo dawno, zawiera obszerne wyjaśnienie wspomnianych wyżej Pawłowych formuł na temat umierania i zmartwychwstania wraz z Chrystusem.

${ }^{41}$ Por. Pascha II, s. 73.

${ }^{42}$ Hryniewicz bardzo często podkreśla ontologiczny wymiar uczestnictwa człowieka w misterium Chrystusa i sprzeciwia się pojęciu moralnego naśladowania, które można by odczytać w duchu pelagianizmu. Dlatego dokonuje wyjaśnienia zbawczego wpływu Chrystusa przez kategorię przyczynowości osobowej oraz tłumaczy, że naśladowanie jest w konsekwencji uczestnictwem. Dokonuje także w innym miejscu podziału na wymiar subiektywny i obiektywny w rzeczywistości zbawczej. Por. Pascha I, s. 441. Wymiar obiektywny, to prawda, że cała ludzkość została zbawiona przez Chrystusa. Subiektywny zaś wskazuje na potrzebę przyjęcia tego daru i współpracy z nim, akcentuje wysiłek człowieka, choć nie ma on nic wspólnego z autosoterią. Analizując wymienione wyżej Pawłowe cytaty, zwłaszcza 2 Kor 4,10-11, niektórzy uczeni dyskutowali nad naturą udziału w cierpieniu Chrystusa, tzn. czy jest on realny, ontologiczny, czy stanowi jedynie wyraz elokwentnej retoryki. Wyrazem tego typu rozterek są m.in. rozważania C. Merrill Proudfoot: „The basic problem in the interpretation of these passages [pas- 
w odkupieńczym akcie Chrystusa jest chrzest, który zespala tajemniczą wspólnotę losu z Chrystusem. „Sakramentalny obrzęd Kościoła pozwala chrześcijaninowi wejść w kontakt ze śmiercią i zmartwychwstaniem Zbawiciela. Raz zapoczątkowany, kontakt ten przedłuża się przez ustawiczne, trwałe uczestnictwo $\mathrm{w}$ paschalnym akcie odkupienia. Dokonuje się to przez cierpienie ( $\mathrm{Rz} 8,17)$, trud apostolski (2 Kor 4,10-12), samo ofiarne

sages like 2 Cor 1:5; 2 Cor 4:10; Phil 3:10; Rom 8:17; or Col 1:24] is this: Are we dealing here with a realistic «Christ-mysticism» or with the milder concept of the imitation of Christ? Does Paul believe his suffering is in some real way the suffering of Christ, or is he simply using vivid metaphor to say that his suffering is like that of Christ, or that it has its origin in his service to Christ". Zob. C. Merrill Proudfoot, Imitation or Realistic Participation? A Study of Paul's Concept of Suffering with Christ, w: "Interpretation" 1963, nr 17, s. 140. Autor zastanawia się czy Paweł Apostoł rzeczywiście wierzy, że jego cierpienie jest w jakiś rzeczywisty sposób cierpieniem Chrystusa czy po porostu używa żywej metafory, aby powiedzieć, że jego cierpienie jest podobne do cierpienia Chrystusa lub też ma swoje źródło w służbie Jemu. Zdaniem D. Kurek-Chomycz, wyrażonym w artykule: "Always Carrying the Dying of Jesus In the Body" (2 Cor 4,10). Apostolic Suffering as Participation In the Dying and the Life of Jesus, and as an Epiphany of God's Power, w: eds. T. Merrigan, F. Glorieux, „Godhead Here in Hiding”: Incarnation and the History of Human Suffering, Leuven 2005, [w przyg. do druku], tego rodzaju dylematy wynikają przede wszystkim z samego niezrozumienia tego, co jest realne. Powyższe stwierdzenie Proudfoot, które sama cytuje, przedstawia jej zdaniem bardzo uproszczoną perspektywę rzeczywistości - jak gdyby była zewnętrznym przedmiotem, gotowym do schwytania. Tymczasem Kurek-Chomycz wykazuje w swym artykule, że dostęp do rzeczywistości niewidzialnej jest możliwy tylko przez widzialną mediację, w tym przypadku - śmierć i życie zmartwychwstałego Jezusa manifestują się w Pawłowej apostolskiej egzystencji. W takim świetle, rozróżnienie na coś, co jest subiektywne i obiektywne, traci na znaczeniu. Autorka wzmacnia też swoją argumentację odwołując się do perspektywy wcielenia, które ukazuje, że moc Boża objawia się w ludzkim ciele. Zob. tamże, s. 5. Również francuski myśliciel, M. L. Cheaveau, wykazuje negatywne tendencje do dzielenia rzeczywistości na dwie autonomiczne rzeczywistości: boską i ludzką oraz lęk przed ich połączeniem. To, co boskie jawi się jako istniejące gdzieś daleko i jest przedmiotem ludzkich wysiłków, by je zdobyć. Niczym platoński świat idei boskich i marny świat ludzi, którzy usiłują się na nich wzorować. Tymczasem to, co ludzkie (subiektywne) żyje już w obrębie rzeczywistości boskiej, choć musi być mediowane by było widoczne. Cheaveau wyjaśnia, że obecność Chrystusa po zmartwychwstaniu jest inna i dlatego istnieje konieczność mediacji poprzez to co widzialne. Por. L. M. Chauvet, Symbol and Sacrament. A Sacramental Reinterpretation of Christian Existence, trans. S. Madigan, M. Beaumont, Collegeville 1995, s. 84-90. Zdaniem Hryniewicza problem ten wyjaśnia idea bogo-człowieczeństwa, która niweluje wszelkie tego typu podziały. 
życie (Ga 2,19), śmierć (2 Tm 2,11) i zmartwychwstanie (Rz 6,8)”43. Dlatego lubelski teolog konstatuje: ten, kto cierpi, umiera wespół z Chrystusem, przez Niego już za życia doznaje mocy zmartwychwstania. Dzieje się tak dlatego, że egzystencja chrześcijańska, od początku do końca, jest ustawicznym uczestnictwem w paschalnym odkupieńczym akcie Chrystusa ${ }^{44}$.

\section{ZAKOŃCZENIE}

Wacław Hryniewicz podkreśla, że śmierć, zmartwychwstanie i posłanie Ducha nie dotyczy jedynie losu Chrystusa. Ponieważ wszystko, co czynił było dla człowieka, także Jego wydarzenie paschalne określa ludzką egzystencję. Chodzi o urzeczywistnienie się Chrystusowego dzieła odkupienia w każdym człowieku, który chce zrealizować swoje człowieczeństwo oraz osiągnąć spełnienie w Bogu. Rzecz dokonuje się w formie osobowego uczestnictwa człowieka w tym, co Chrystusowe, a zasadniczą przestrzenią realizacji jest założony przezeń Kościół. Lubelski teolog stwierdza: „wszystko, czego Bóg dokonał w Jezusie jako w pierwowzorze - od uniżenia aż do Jego wywyższenia - staje się udziałem ludzi w tajemnicy Kościoła”45.

Streszczenie. Zjednoczenie z Chrystusem w Kościele na podstawie trylogii paschalnej Wacława Hryniewicza OMI.

Autorka podejmuje w swym artykule refleksję nad interpretacją zjednoczenia człowieka z Chrystusem w przestrzeni chwalebnego Ciała Chrystusa, jaką jest Kościół, myśl prezentowaną przez Wacława Hryniewicza. Opierając się głównie na największym dziele lubelskiego dogmatyka - trylogii paschalnej - wyjaśnia w jaki sposób, za sprawą wydarzeń zbawczych Chrystusa uobecnianych w Kościele, możliwe jest osobowe zjednoczenie człowieka z Bogiem. Prezentuje najpierw krótką genezę Kościoła, jego naturę i zadanie, a wszystko to w komplementarnym kluczu hermeneutycznym. Następnie omawia zagadnienie zjednoczenia z Chrystusem, które ks. prof. Wacław Hryniewicz wyjaśnia za pomocą takich kategorii, jak: przyczynowość osobowa, naśladowanie, uczestnictwo oraz prawo synergizmu.

Słowa kluczowe: zjednoczenie z Chrystusem; Kościół jako Ciało Duchowe Chrystusa; przyczynowość osobowa; naśladowanie i uczestnictwo; prawo synergizmu.

\footnotetext{
${ }^{43}$ Pascha II, s. 73.

${ }_{44}$ Por. tamże.

${ }^{45}$ Pascha II, s. 51.
} 
Abstract. Unification with Christ in the Church according to Waclaw Hryniewicz's paschal trilogy. The author takes up a reflection on Waclaw Hryniewicz's interpretation of man's unification with Christ in the Church as the spiritual Body of Christ. She bases mainly on the main work of the theologian, called the paschal trilogy. She explains the possibility of personal unification with God achieved by Christ's life, death, and resurrection, and the descent of the Holy Spirit that are actualized in the Church. She takes a brief look at the genesis of the Church, her nature and tasks, all of that in the hermeneutic key of the complementarity. The author addresses the question of unification with Christ, which Waclaw Hryniewicz OMI presents in terms of the personal causation, imitation and participation, and the synergism principle.

Keywords: unification with Christ; Church as the spiritual Body of Christ; personal causation; imitation and participation; synergism principle. 